\title{
Analysis of the Exposure to Losses of Brazilian ETFs According to the Value at Risk (VAR) and Expected Shortfall (ES) Market Risk Assessment Techniques
}

\author{
Getúlio Alves de Souza Matos ${ }^{\dagger}$ \\ Universidade Federal de Minas Gerais - UFMG \\ Robert Aldo Iquiapaza ${ }^{\Omega}$ \\ Universidade Federal de Minas Gerais - UFMG \\ Bruno Pérez Ferreira ${ }^{7}$ \\ Universidade Federal de Minas Gerais - UFMG
}

\begin{abstract}
For investors, Exchange-Traded Funds (ETFs) are securities structured as portfolios that replicate financial market indexes, but with the facility of being traded as stocks. The aim of the study was to analyze the risk exposure of Brazilian ETFs, compared to the Ibovespa index and the corresponding BMFBovespa indexes. For the present analysis the methodology of Value-at-Risk (VaR) at 5\% was used, with historical simulation, coupled with the Expected Shortfall (ES) methodology, also at 5\%. Next, the Unplanned Divergence (DnP) was used as a tracking error mechanism . The Monte Carlo simulation for replication of the verified values was also used, considering the previous profitability measures. The results presented the frequency distributions for the losses, and those lower than the VaR, which characterizes the expectation of loss measured by the ES. All ETFs presented losses and exposure to risk greater than those observed for the Ibovespa benchmark and its respective benchmark indexes.
\end{abstract}

Keywords: Risk. ETF. Expected shortfall. Unplanned divergence. Monte Carlo.

*Author for correspondence:

\footnotetext{
${ }^{t}$. Master by the Business Administration Post-Graduation and Research Center CEPEAD - UFMG

Link: Doctorate candidate in Business Administration (Finance) by the Business Administration Post-Graduation and Research Center - CEPEAD - UFMG Address: Avenida Antônio Carlos Faculdade de Ciências Econômicas - Belo Horizonte - MG - Brazil

E-mail: getuliomatos@yahoo.com.br
}

\author{
${ }^{\Omega} \mathrm{PhD}$ in Business Administration Post- \\ Graduation and Research Center of Minas \\ Gerais Federal University \\ Link: Adjunct Professor of Minas Gerais \\ Federal University \\ Address: Av. Antônio Carlos, Pampulha, Belo \\ Horizonte - MG - Brazil \\ E-mail: rbali@ufmg.br \\ Phone \#: (55 31) 3409-7046
}

$\mathrm{PhD}$ by the Post-Graduation and Research Center - CEPEAD UFMG

Link: Professor of the PostGraduation and Research Center CEPEAD - UFMG

Address: Av. Antônio Carlos, Pampulha, Belo Horizonte MG - Brazil - E-mail: brunoperez@ufmg.br Phone \#: (55 31) 34097234

Editor's Note: The article herein was accepted by Emerson Mainardes 


\section{INTRODUCTION}

he Exchange-Traded Funds (ETFs, or, in Portuguese, Fundos de Índices

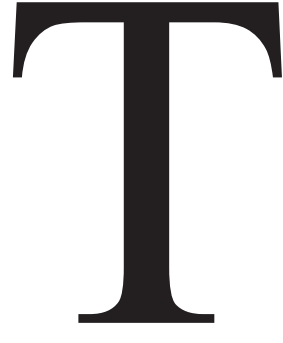

Negociados) are financial market products that have the main objective of offering the profitability of an index, by means of a passive investment strategy, but with the flexibility of stock negotiations. Also called trackers, ETFs replicate the composition of a certain index, according to specific regulations (BM\&FBOVESPA, 2008).

In Brazil, the ETF market began in 2004, with the aim of replicating the profitability of the IBrX-50 index. According to the BM\&FBOVESPA (2008), for the Brazilian market, the operational costs of the operation by means of ETFs are lower than in the individual negotiation of their component stocks. Such fact is noticeable because, isolatedly, the costs of negotiation of each transaction added to the dynamism required from the operations to maintain the weighing of the index, makes this procedure more onerous.

Thus, ETFs issue quotes that may be purchased and redeemed, and can be continuously traded, like stocks (DEVILLE, 2008). However, their value is calculated based on the variation in prices of the assets of their respective indexer (ARAGÃO, 2011). With this, according to Ramaswamy (2011), an ETF Fund should provide the investor with liquidity and reduce exposure to risks when compared to variable income investment alternatives.

Thus, this article assesses the risk exposure, specifically market risk typology, for the main ETF funds traded on the BM\&FBovespa. Thus, the research question addressed in the study was the following: what is the exposure to losses, in the view of shareholders, for the major ETFs traded on the BM\&FBovespa, as per the Value at Risk (VaR) and Expected Shortfall (ES) market risk assessment techniques?

Having the main objective of answering this research question, the following specific objectives were listed:

- Survey of the daily variation in quota prices (daily returns) of the ETFs traded on Bovespa up until 2011, i.e., the following funds: BOVA11, BRAX11, CSMO11, MILA11, MOBI11, SMAL11, FIND11, GOVE11, ISUS11, and PIBB11;

- Measurement of the exposure to losses of the analyzed funds by means of the application of the VaR and ES risk measurement techniques, historical approaches, and Monte Carlo simulation; and 
- Comparison of the results between the ETF funds, the indexers tied to each of them, and the Ibovespa index, measured by means of the Unplanned Divergence (DnP) tracking error technique conjugated to risk measurement by means of the techniques already emphasized.

This risk analysis developed by the research aims at contributing to the execution of studies about ETF funds, given the trading expansion of the shares of these funds in the variable income market in Brazil, as well as the growing offer of new negotiable funds each year. It is worth mentioning that this article initially provides a presentation of the ETF funds, emphasizes the VaR and ES risk analysis techniques, and the conjugation with the DnP, presents the methodology developed by the study, and discusses the results and their considerations.

\section{THE ETF FUNDS}

Created in the United States in 1989, and introduced in the North-American market in 1992, the Exchange-Traded Funds showed rapid growth, reaching the mark of $2.5 \%$ in 2001 of the resources invested in mutual stock funds in the United States (POTERBA; SHOVEN, 2004). According to Dellva (2001), the number of ETFs traded on the American Stock Exchange (AMEX) doubles every year, and with future predictions of annual growth between $30 \%$ and $50 \%$. At the end of 2011, there were more than 3,000 ETFs, representing more than USD 1.351 billion in assets under administration, offered by 155 sponsors and marketed in more than 40 stock exchanges around the world (BLACKROCK, 2011).

However, being a relatively new financial product, there are few studies on ETFs, including in the North American market (DEVILLE, 2008; JARES; LAVIN, 2004).

In 1992, Standard and Poor's Depositary Receipts was the first ETF traded, based on the S\&P 500 Index of the AMEX (American Stock Exchange). Finding less restrictive legislation in Luxembourg, the Morgan Stanley Bank created the "Optimized Portfolios as Listed Securities" (OPALS), ETFs listed in the stock market of Luxembourg, that reflect different indexes of the MSCI (Morgan Stanley Capital Indexes).

In 1996, Morgan Stanley, AMEX, and Barclays Global Investment, jointly created the World Equity Benchmarks (WEBS), similar to the OPALS, however traded on the AMEX and organized as a mutual fund. In 2000, the WEBS became known as iShares MSCI (DEVILLE, 2008). 


\subsection{THE ETF TRADING MECHANISM}

Traded in a similar manner to stock, the ETFs are a weighted group of different stock that mirrors the composition of an index. The composition of an ETF is based on the purchase of a portfolio of stock by an authorized financial institution with the consequent receipt of ETF quotas, which are then sold to other investors. In other words, the investor buys a stock portfolio, which, according to BOVESPA (2008), decreases the probability and the risk of loss. This negotiation takes place through brokers, and, following the example of stock trading, investors can buy bonds and sell short. In addition to this possibility, intraday trading causes the ETFs to significantly differ from the mutual fund market.

According to Poterba and Shoven (2004), these differences cause mutual funds and ETFs to be suitable investments for different investor profiles. The first ones, intended for investors who conduct many small value negotiations and do not ascribe much value to liquidity. The second one, for investors who desire short-term liquidity and perform large quantity negotiations.

On the other hand, Gastineau (2004) argues that ETFs and indexed mutual funds are competing products, being good substitutes for each other, despite the fact that the ETF presents greater tax simplification. In addition to this, it is mentioned that ETFs have lower administration rates compared to traditional mutual funds (BOVESPA, 2008). However, the trading of ETFs involves brokerage fees that do not exist in mutual funds.

It should be noted that the prices of ETFs may be different from prices of the sums of assets that make up the index, called the net asset value (NAV), or book value. Although this difference exists, it is constrained by the capacity of the authorized financial institutions to create and redeem the bonds. If the value of the ETF is well above the NAV, the financial institutions can buy the securities at lower prices and make new issuance of ETFs. If the ETF is lower in price in relation to the shares, the same institutions may purchase ETFs and redeem them in order to purchase securities (POTERBA; SHOVEN, 2002).

According to the BM\&FBOVESPA (2008), the trading price of an ETF responds to pressures in supply and demand of these securities, which will also reflect the stock market conditions that comprise the fund portfolio, in addition to Brazil's economic situation, as well as the general expectations of investors. Thus, the negotiated ETF value may be different from its benchmark value, also called Indicated Optimized Portfolio Value (IOPV, in Portuguese, Valor Indicativo Otimizado do Portfólio). 
According to Blackrock (2010), the IOPV represents the estimated intraday value of an ETF, based on the latest negotiated values of the underlying assets traded to the portfolio represented by the title. The values are then weighted according to the constitution of the index.

Another indicator used for the evaluation of the ETF is its Net Asset Value (NAV, Valor Líquido de Ativos, or book value). Calculated in a manner similar to the evaluation of mutual fund shares, the NAV is obtained by the total assets minus their debts.

\subsection{ETFS IN BRAZIL}

The market regulation of ETFs in Brazil occurred with the publication of CVM Resolution $\mathrm{n}^{\mathrm{o}} 359$, of January 2002, which defined the ETFs as a "pool of resources for the application in bond and security portfolio that seeks to reflect the variations and the return of a benchmark index, for an unspecified period" for specific market indexes acknowledged by the CVM, to which the fund's investment policy is related.

For the ownership structure of the fund, Brazilian legislation establishes that the right to vote in general shareholder meetings of the companies that comprise the ETF must be established by the fund. In case of the exercise of voting rights by the administrator, the vote must be justified to CVM, if so requested. In case of interest of exercise by the shareholder, the administrator must provide for the loan of the shares required to vote. It should be noted that funds cannot also have holders of more than $49 \%$ of the quotas of the fund.

The resolution also stipulates that the liquidity of the security can be fostered by the stock exchange or by an organized over-the-counter market entity, according to the legislation in force, by means of market makers for the quotas of the fund. In this case, the market makers should be disclosed together with the fund's information.

Academic studies of the Brazilian market ETFs are relatively recent. Farias (2009) found no increases in liquidity in the Ibovespa, given the influence of the PIBB11 ETF. Yang and Wang (2010) tested the predictability of returns of 18 international ETFs, among them a Brazilian ETF, and concluded that there is no possibility of gains in daily forecasts. Maluf (2011) did not find a real winning strategy by arbitration between the fundamental value and the negotiated value of the ETF when the effects of data-snooping were not considered. Aragão (2011) studied the effectiveness of pricing and the errors of adherence of ETFs, finding that for certain ETFs, the premiums/discounts can be considerable. 


\section{INVESTMENT RISK ANALYSIS}

According to Beckers (1998), the idea of risk can be understood as the influence of factors on the variation of prices, returns on assets and behaviour of portfolios. This risk may manifest itself as a result of systematic aspects related to the market in which the investments are inserted, so as to constitute a difficult situation for the "development of diversifications". In addition, the risk may be related to non-systematic characteristics, that is, linked to investment alternatives, which may be the object of managerial strategies intended for its reduction by means of efficient portfolios.

According to Duarte Junior (2005), the management of an investment risk involves three important concepts related to the financial market: return, risk and uncertainty. The concept of return can be considered as the capital appreciation at the end of the investment horizon. However, there are uncertainties associated with the return that will be effectively obtained at the end of the investment period, and accordingly, any numerical measure of the uncertainty can be called a risk.

In order to measure the risks of an investment, Jorion (2003) presents the technique of Value at Risk (VaR) that, based on a frequency distribution for the profitability of an investment or asset portfolio, produces the probability of loss and its impact for the investor. Thus, financial institutions structure provisions for assets exposed to losses arising from fluctuations in the financial market.

However, Artzner et al. (1997, 1999) point out mathematical properties that must be observed in the quantitative risk measurement techniques and, with the use of historical simulation, the calculated VaR does not meet the subadditivity property. This result from the fact that, in the case of the historical VaR, it would be necessary for the sum of the assets' risk measurements considered individually to be greater than or equal to the measurement of risk of the investment portfolio. Given this deficiency of the VaR, Acerbi and Tasche (2002) suggest the technique called Expected Shortfall (ES), which considers the effects of results that were lower than those indicated in the VaR.

\subsection{THE VALUE AT RISK (VAR)}

In the words of Jorion (2003, p. 246), the VaR is "the maximum loss in a particular horizon, in such a way that there is a pre-specified probability that current loss will be greater". 
It is a statistical measurement that indicates the level of loss (measured in monetary units) in reference to an expected value, by means of a value determined by a probability in an investment perspective.

Alternatively, according to Jorion (2003), the VaR can be understood as the deviation between the average and the analyzed quantile. According to the author himself, this definition can be even more consistent, since it considers the value of money over time, when considering the deviations between two values on a target date. In these cases, as the interval tends to be low and the average (or expected return) close to zero, the two definitions lead to similar results.

It is, by any one of the possible understandings, a technique for the evaluation of possible losses arising from the behavior of investments, which may be identified through the dispersion of the results of financial investments. Data for the determination of these dispersions is obtained by monitoring the performance of investments over time.

Jorion (2003) formalizes the $\mathrm{VaR}$ as the measurement of a loss in the investments, defined by $c$ :

$$
c=\int_{-V a R}^{\infty} f(x) d x
$$

Where:

$x$ is a specific value for the investment;

$f(x)$ is the continuous function of probability distribution.

According to the author, the VaR calculation of an investment or a portfolio can be developed with the assessment of factors specified in the analysis, so that the impact of each variable and also of the relationship between these variables in the volatility of the return of the investment are verified. Thus, the variation of terms specified in the analysis of factors that influence the returns of an investment is applied to determine possible losses in the application.

\subsection{COHERENT RISK MEASUREMENT PROPERTIES}

According to Artzner et al. $(1997 ; 1999)$, considering a set $\mathrm{V}$ of random variables, the function $\rho: V \rightarrow R$ can be defined as a coherent measure of risk, in case it has the following properties: 
I. Monotonicity: $X, Y \in R, X \leq Y \Rightarrow \rho(X) \geq \rho(Y)$, thus, $X$ and $Y$ belonging to the set of real numbers, where $X$ is less than or equal to $Y$. For the function $\rho$ to be monotonous, the image of this function for $X$ must be greater than or equal to that of $Y$, because $X$ is a result worse than $\mathrm{Y}$;

II. Subadditivity: $X, Y, X+Y \in V \Rightarrow \rho(X+Y) \leq \rho(X)+\rho(Y)$, namely, the risk measurement of a set of assets must be less than or equal to the sum of the measures of risk of each asset, considered individually. This property is related to the reduction of risk through diversification;

III. Positive homogeneity: $X \in V, h \geq 0, h X \in V \Rightarrow \rho(h X)=h \rho(X)$. Therefore, if a constant multiplies the independent term of a function, this constant can be evidenced in the function; and

IV. Translational invariance: $X \in V, \alpha \in R \Rightarrow \rho(X+\alpha)=\rho(X)-\alpha$, so that, if there is a constant term in the independent variable, it can be removed, since it does not constitute a risk factor, as it does not provide variation.

The calculation of the VaR of an investment can be developed by means of (i) historical simulation (ii) analytical methodology and/or (iii) Monte Carlo simulation-SMC. However, with the use of historical simulation, the calculated VaR does not satisfy the property of subadditivity, since it would be necessary that the sum of the measurements of risks of the assets considered individually be greater than or equal to the measurement of risk of the investment portfolio. Due to this, it is worth verifying which is the impact of the use of the Expected Shortfall (ES) in relation to the VaR, since this is a measurement of risk that meets the mathematical properties highlighted by Artzner et al. $(1997 ; 1999)$.

\subsection{THE EXPECTED SHORTFALL (ES)}

According to Acerbi and Tasche (2002), if $\mathrm{X}$ is the loss of return of a portfolio at a specific time on the horizon of time T and $\alpha \in(0,1)$ is the level of confidence. The small drop expected to $\alpha$ probability or the Expected Shortfall of portfolio is defined as:

$$
\left.E S^{(\alpha)}(X)=-\frac{1}{\alpha}\left(E\left[X \mathrm{I}_{\{<x}\right\}\right]-x^{(\alpha)}\left(\mathrm{P}\left[X \leq x^{(\alpha)}\right]-\alpha\right)\right)
$$

where:

$X$ is the series of returns of the analyzed time interval; 
$I_{\{\text {condition }\}}$, the conditioned function, which will be 1 if the condition between the brackets is found and 0 , otherwise;

$x^{(\alpha)}$, the upper $\alpha$ quantile, which is defined below;

$\alpha$, the confidence level; and

$P\left[X \leq x^{(\alpha)}\right]$, the probability of the $\mathrm{X}$-values being less than or equal to the upper $\alpha$ quantile.

The upper $\alpha$ quantile is the smallest among all returns with accumulated frequency greater than $\alpha$, that is, the infimum of the set formed by the returns with accumulated frequency greater than $\alpha$ :

$$
x^{(\alpha)}=\inf \{x \in \mathbf{R} \mid P[X \leq x]>\alpha\}
$$

As highlighted out by Silva et al. (2005), the ES can be defined as the average of the worst $\alpha \%$ returns of time interval of the analyzed investment, i.e. by the ES, all returns less than or equal to the upper $\alpha$ quantile should be selected; limit the weight associated with the upper $\alpha$ quantile, until the accumulated weight does not exceed the limit defined by the level of confidence $\alpha$. Therefore, the ES is obtained by the average symmetric of these weighted returns.

For continuous probability functions, the ES can be defined as:

$$
E S^{(\alpha)}(X)=-\frac{1}{\alpha} \int_{0}^{\alpha} F^{\leftarrow}(p) d p
$$

Where:

$$
F^{\leftarrow}(p)=\inf \{x \mid F(x) \geq \alpha\}
$$

$F(x)=P\left[X \leq x^{(\alpha)}\right]$ is the distribution function related to the probability of the $\mathrm{X}$ values being less than or equal to the upper $\alpha$ quantile;

$\alpha$, the probability used in the calculation of the ES; and $p$, the variable to be included in the function, with limits 0 and $\alpha$.

In another manner, the $E S$ can be obtained by means of the following specification [Acerbi and Tasche (2002)]:

$$
E S^{(\alpha)}=T C E^{(\alpha)}+(\lambda-1)\left(T C E^{(\alpha)}-V a R^{(\alpha)}\right)
$$


Where: $\operatorname{VaR}^{(\alpha)}$ is the Value at Risk defined for the $\alpha$ loss probability;

$\lambda=\left\{P\left[X \leq x^{(\alpha)}\right] / \alpha\right\} \geq 1$, the ratio between the distribution function related to the probability of the X-values being less than or equal to the upper $\alpha$ quantile and the $\alpha$ itself; and

$T C E^{(\alpha)}(X)=-E\left\{X X \leq x^{(\alpha)}\right\}$, the conditional expectation for values of $\mathrm{X}$ being less than or equal to the upper $\alpha$ quantile, or the 'tail conditional expectation' (Artzner et al., 1997).

Zhu and Galbraith (2011) emphasize the effect of the VaR loss that can be estimated through the ES due to possible imbalances in the distribution of returns of an investment. Because the application of the ES incorporates the effect of the extreme values in the evaluation of exposure to losses of a portfolio.

The use of ES in risk assessment is highlighted by So and Wong (2010), as well as by Hoogerheide and van Dijk (2010), in measuring the regulatory capital required for exposure to losses. These authors suggest the application of this risk analysis technique to establish adequate provisions in financial institutions.

\subsection{UNPLANNED DIVERGENCE}

The DnP risk measurement, according to Pena (2005), consists of a technique that evaluates a deviation registered in the performance of investments in relation to the goal of profitability or the indexer stipulated to a fund or investment asset - as in the case of this study, ETF funds. Such application of tracking error techniques for the evaluation of ETF funds is suggested by Rompotis (2011).

The calculation using this technique starts with the difference between the profitability of the investments in relation to a performance benchmark such as, in the context of this study, the profitability of the Ibovespa index, a factor that consolidates it as a measure of risk based on tracking error techniques. The DnP is obtained by the difference between the return on investments and the benchmark:

$$
D n P=r_{t}-I_{t}
$$

Where:

$r_{t}$ is the return of the fund in moment $t$; and 
$I_{t}$ corresponds to the goal of the benchmark at the moment $t$.

Thus, the DnP allows to verify if the returns of the investments in ETF funds present superior performance or not in relation to the chosen references, Ibovespa and ETFs indexers over time. This technique is geared towards the detection of possible differences in the dynamics of the returns of investments in relation to the referential or benchmark. Coupled with the Expected Shortfall (ES), the DnP is a coherent measurement of risk, as Artzner et al. (1997, 1999) highlight. In other words, the net returns on investments in relation to a performance goal, according to Rockafellar et al. (2003), represent a consistent measure of deviation.

\section{THE METHOD}

\subsection{STEP-BY-STEP TECHNIQUE}

The development of the assessment of exposure to losses of the main ETF funds traded on the BM\&FBovespa using $\mathrm{VaR}$ and $\mathrm{ES}$, followed the routine of scenario analysis highlighted by Riskmetrics, which involved a historical approach and Monte Carlo simulation. Risk assessments followed the following steps:

I The frequency distributions and descriptive statistics of the BOVA11, CSMO11, DIVO11, ECOO11, FIND11, GOVE11, ISUS11, MATB11, MILA11, MOBI11, PIBB11, SMAL11, UTIP11, and XBOV11 funds were verified;

Approach based on past data

II. The values were measured for VaR at 5\% for each of the ETF funds;

III. The results below the VaR were grouped and used to calculate the ES at 5\%, based on the average of the results below the $\mathrm{VaR}$ at $5 \%$;

IV. The performance impacts identified in the VaR and ES in terms of daily percentage losses were measured to illustrate the measurement of the risk identified by the two techniques;

V. Steps II, III, and IV were replicated for the analysis of the results of the DnP of each ETF against Ibovespa and its respective indexer;

Approach based on Monte Carlo simulation

VI By means of the frequency distributions identified for the profitability of the ETF funds 10,000 daily returns were simulated using the Monte Carlo simulation technique; 
VII. The simulations were grouped and used to calculate the ES at 5\% based on the average of these simulated results that were below the VaR at 5\%;

VIII. Steps VI and VII were replicated for the analysis of the results of the DnP for each simulated return against the surveyed benchmarks.

The statistical analyses and simulations were performed by means of Microsoft Excel ${ }^{\circledR}$ and R 3.0.1. softwares.

\subsection{THE DATA}

In the analysis below, the daily returns of ETFs listed in BM\&FBOVESPA will be used, according to Table 1.

\begin{tabular}{|c|c|c|}
\hline Series & $\begin{array}{l}\text { Benchmark } \\
\text { Index }\end{array}$ & Comments \\
\hline BOVA11 & Ibovespa & $\begin{array}{l}\text { Based on the Ibovespa, index composed of stock issued by companies that } \\
\text { account for more than } 80 \% \text { of the number of transactions and financial } \\
\text { volume of the Stock Exchange. First return in } 12 / 3 / 2008 \text {. }\end{array}$ \\
\hline CSMO11 & CSMO & $\begin{array}{l}\text { Based on the BM\&FBOVESPA Consumption index, which measures the } \\
\text { return of an investment in a theoretical portfolio composed of shares of } \\
\text { companies representing cyclical and non-cyclical consumption sectors. First } \\
\text { return on } 2 / 24 / 2010 \text {. }\end{array}$ \\
\hline DIVO11 & IDIV & $\begin{array}{l}\text { Based on the Dividend Index (IDIV), which measures the behavior of stock } \\
\text { of companies that have excelled in terms of remuneration of investors, in the } \\
\text { form of dividends and interest on capital. First return on } 01 / 31 / 2012 \text {. }\end{array}$ \\
\hline ECOO11 & ICO2 & $\begin{array}{l}\text { Based on the Carbon Efficient Index (ICO2), consists of the stock of the } \\
\text { companies participating in the IBrX-50 index that adopt transparent practices } \\
\text { with respect to their emissions of greenhouse gases (GHG) emissions, } \\
\text { considering their degree of GHG emissions efficiency, in addition to the free } \\
\text { float of each one of them. First return on } 06 / 15 / 2012 \text {. }\end{array}$ \\
\hline FIND11 & IFNC & $\begin{array}{l}\text { Based on the Financial Index (IFNC), which consists of the shares issued by } \\
\text { companies from the sectors of financial intermediary companies, } \\
\text { miscellaneous financial and pension and insurance services. First return on } \\
4 / 8 / 2011 \text {. }\end{array}$ \\
\hline GOVE11 & IGCT & $\begin{array}{l}\text { Based on the Corporate Governance Trade Index (IGCT), which is } \\
\text { composed by the shares of the IGC and that simultaneously meets the criteria } \\
\text { of liquidity. First return on } 11 / 28 / 2011 \text {. }\end{array}$ \\
\hline ISUS11 & ISE & $\begin{array}{l}\text { Based on the Corporate Sustainability Index (ISE), which aims at reflecting } \\
\text { the return of a portfolio composed of shares from companies with recognized } \\
\text { commitment to social responsibility and corporate sustainability, as well as } \\
\text { the induction of good practices in the Brazilian business environment. First } \\
\text { return on } 01 / 19 / 2012 \text {. }\end{array}$ \\
\hline MATB11 & IMAT & $\begin{array}{l}\text { Based on the Basic Materials Index, it measures the behavior of companies } \\
\text { stock representing the Basic Materials sector. First return on } 02 / 01 / 2012 \text {. }\end{array}$ \\
\hline MILA11 & MLCX & $\begin{array}{l}\text { Based on the BM\&FBOVESPA MidLarge Cap index, which measures the } \\
\text { return on an investment in a theoretical portfolio composed of shares issued } \\
\text { by companies with the largest Capitalization Values listed on the Stock } \\
\text { Exchange. First return on } 12 / 31 / 2008 \text {. }\end{array}$ \\
\hline MOBI11 & IMOB & $\begin{array}{l}\text { Based on the BM\&FBOVESPA Real Estate index, which measures the } \\
\text { return on investment in a theoretical portfolio composed of shares issued by } \\
\text { the more representative companies of the ones listed in the following sectors } \\
\text { of the real estate business: civil construction, real estate brokerage, and real } \\
\text { estate exploitation. First return on } 2 / 24 / 2010 \text {. }\end{array}$ \\
\hline
\end{tabular}




\begin{tabular}{|c|c|l|}
\hline Series & $\begin{array}{c}\text { Benchmark } \\
\text { Index }\end{array}$ & \multicolumn{1}{c|}{ Comments } \\
\hline PIBB11 & IBrX-50 & $\begin{array}{l}\text { Based on the Brazil Index }-50 \text { (IBrX-50), which measures the return on an } \\
\text { investment in a theoretical portfolio composed of 50 selected among the } \\
\text { most actively traded stock on the BM\&FBOVESPA in terms of liquidity. } \\
\text { First return on 7/27/2004. } \\
\text { Based on the Small Cap BMFBOVESPA index, which measures the return } \\
\text { on an investment in a theoretical portfolio composed of shares issued by } \\
\text { companies with the lowest Capitalization Values listed on the } \\
\text { Exchange. First return on 12/12/2008. } \\
\text { Based on Public Utility Index (UTIL), it measures the behavior of stock of } \\
\text { companies representing the public utilities sector (electricity, gas, water and } \\
\text { sanitation). First return on 02/15/2012. } \\
\text { Based on the Ibovespa index, composed of stock issued by companies that } \\
\text { account for more than 80\% of the number of business and financial volume } \\
\text { of the Stock Exchange. First return on 11/12/2012. }\end{array}$ \\
\hline UTIP11 & SMLL \\
\hline
\end{tabular}

Table 1 - ETFs used in the evaluation of the $V a R$ and $E S$ techniques

Source: BM\&FBOVESPA, 2013.

Data used in the development of the simulations refer to dates between the start of the activities of each fund and 29/08/2013. The choice for use of all of the observations of each index, in detriment of the selection of a specific period is due to the maximum possible approach of the quantity of funds in the period under review. Thus, other approaches that comprise predetermined periods would omit the existence of a fund.

\section{RESULTS}

The results were divided into two groups: the first one discusses the comparison of ETFs with the Ibovespa (5.1), and the second one refers to the comparison of ETFs with their corresponding indexers (5.2). These two groups were further subdivided into two other topics concerning the historical analysis and the simulation analysis, respectively.

\subsection{COMPARISON OF THE ETFS WITH THE IBOVESPA}

\subsubsection{Analysis of Historical ETFs Data against Ibovespa}

This block presents the results of the risk analysis for the Ibovespa market benchmark, since this is the main indicator of the evolution of prices of the Brazilian stock market. In addition, ETFs are considered as an alternative investment designed to reduce exposure to risks that the agents could be exposed to through an isolated investment in an share or on the broad market. Thus, an ETF can provide the investor with the performance of a specific sector of the Stock Exchange, distinguishing the ETFs from other investment alternatives that exist on the capital market.

Table 2 shows the descriptive statistics for returns of the funds, as well as the indexes used for the performed comparisons. 
A first observation is about the differences in liquidity of the funds quotas, since only two of them (BOVA11 and PIBB11) were traded every day since the beginning of the fund up until 08/29/2013. Certain funds had less than 60\% trading during their corresponding periods. Apparently, there would be no problem with the low liquidity of the funds quotas, since during the days when there is no trading, the quotas can be bought back at book value. However, according to the results of Aragão (2011), certain funds may be negotiated with premiums or discounts in relation to the book value, by which the risk in these cases would be far greater. Observing the average, in general, the funds had a positive average daily return since they were created. The following funds did not follow the rule: XBOV11, MOBI11, UTIP11, and MATB11. The higher returns were obtained by PIBB11 and MILA11 funds, whereas the UTIP11 presented the sharpest loss. Using the variation coefficient, the fund with most risk was FIND11.

Table 2 - Descriptive Statistics of the Assets Under Analysis

\begin{tabular}{|c|c|c|c|c|c|c|c|}
\hline ETF/Index & Average & $\begin{array}{l}\text { Standard } \\
\text { Deviation }\end{array}$ & Maximum & Minimum & $\begin{array}{c}\text { Percentile } \\
10 \% \\
\end{array}$ & $\begin{array}{c}\text { Percentile } \\
\mathbf{9 0 \%} \\
\end{array}$ & $\begin{array}{c}\text { Number of } \\
\text { Observations }\end{array}$ \\
\hline XBOV11 & -0.0516 & 1.412148 & 3.804751 & -6.25324 & -1.79609 & 1.595475 & 195 \\
\hline BOVA11 & 0.027892 & 1.59745 & 8.432035 & -9.02341 & -1.88931 & 1.847956 & 1171 \\
\hline ECOO11 & 0.008476 & 1.384604 & 5.056401 & -3.95905 & -1.70622 & 1.562644 & 297 \\
\hline CSMO11 & 0.060129 & 1.159593 & 6.357963 & -6.07123 & -1.26718 & 1.24457 & 873 \\
\hline MOBI11 & -0.03089 & 1.901755 & 8.677154 & -8.92391 & -2.38812 & 2.176448 & 873 \\
\hline MILA11 & 0.044283 & 1.400726 & 15.86626 & -9.15204 & -1.01409 & 1.212897 & 1171 \\
\hline SMAL11 & 0.08697 & 1.425869 & 8.840951 & -8.48307 & -1.40692 & 1.525605 & 1171 \\
\hline UTIP11 & -0.08843 & 1.604446 & 5.532579 & -17.8930 & -1.44247 & 1.342201 & 319 \\
\hline DIVO11 & 0.007814 & 1.056601 & 3.558228 & -4.55388 & -1.22773 & 1.320989 & 390 \\
\hline FIND11 & 0.000776 & 1.398708 & 8.91728 & -5.66715 & -1.6748 & 1.526331 & 594 \\
\hline GOVE11 & 0.011577 & 1.048378 & 3.717516 & -4.53367 & -1.26969 & 1.256236 & 450 \\
\hline MATB11 & -0.01622 & 1.638271 & 9.547779 & -7.16121 & -1.95012 & 1.534945 & 389 \\
\hline ISUS11 & 0.032847 & 1.273654 & 13.01507 & -12.9712 & -1.15029 & 1.167049 & 450 \\
\hline PIBB11 & 0.05083 & 1.935845 & 16.71584 & -13.8747 & -2.03424 & 2.096353 & 2250 \\
\hline IBOV & 0.033448 & 1.847695 & 13.67942 & -12.0961 & -2.05655 & 2.03437 & 2390 \\
\hline IBRX & 0.049864 & 1.751357 & 13.69912 & -12.1853 & -1.87226 & 1.940314 & 2390 \\
\hline ICO211 & 0.011491 & 1.202225 & 5.286022 & -8.32851 & -1.33905 & 1.437236 & 742 \\
\hline ICON11 & 0.049278 & 1.53334 & 11.82871 & -9.67163 & -1.54762 & 1.658277 & 1646 \\
\hline IMOB11 & -0.02481 & 2.561127 & 17.77555 & -16.2905 & -2.66091 & 2.690745 & 1401 \\
\hline MLCX11 & -0.00747 & 1.870281 & 13.63002 & -12.1156 & -1.81457 & 1.839132 & 1321 \\
\hline SMLL11 & 0.018924 & 1.6545 & 12.88809 & -10.8051 & -1.55183 & 1.551755 & 1321 \\
\hline UTIL11 & 0.081247 & 1.901289 & 52.57144 & -11.0359 & -1.57617 & 1.669035 & 1975 \\
\hline IDIV11 & 0.06113 & 1.605353 & 12.07724 & -10.3789 & -1.63724 & 1.733133 & 1893 \\
\hline IFNC11 & 0.062619 & 2.140508 & 20.3212 & -12.8484 & -2.18871 & 2.276859 & 2142 \\
\hline IGCT11 & 0.03659 & 1.824986 & 14.96131 & -11.816 & -1.97572 & 1.948122 & 1893 \\
\hline IMAT11 & 0.029351 & 2.186258 & 13.38593 & -14.4471 & -2.41943 & 2.340764 & 1893 \\
\hline ISEE11 & 0.044373 & 1.740317 & 14.47929 & -10.3863 & -1.84789 & 1.847594 & 1914 \\
\hline IBRX50 & 0.044949 & 1.834171 & 13.83365 & -12.8964 & -1.99122 & 2.036722 & 2390 \\
\hline
\end{tabular}


From the estimated returns for each ETF fund and for the Ibovespa, the VaR and ES were evaluated, both relative to the $5 \%$ percentile of empirical distribution. These measurements of exposure to risks were consolidated in the results of percentage losses and losses against the Ibovespa benchmark. The results are presented in Table 3.

With the $\mathrm{VaR}$ at $5 \%$, it was noticed that the greatest exposure to risk was observed in ETFs MOB11 and PIBB11, whereas the smallest exposure was of DIVO11 and CSMO11. However, when considering an opportunity cost, in this case the one indicated by the Ibovespa benchmark, the PIBB11 presented the worst relative performance. The best performance with opportunity cost was presented by CSMO11. For the VaR of the DnP, the largest loss of value can be attributed to MOBI11 and FIND11 ETFs, and the smallest loss of value to BOVA11.

Table 3 - Results of the Market Risk Evaluation, Using the VaR and ES Techniques for ETF Funds According to the Exposure to Losses in Daily Profitability, Ibovespa Benchmark Display in the Period, and the Performance of the ETF Against Said Benchmark

\begin{tabular}{c|c|c|c|c|c|c}
\hline ETF & \multicolumn{5}{|c}{ VaR $(5 \%)$} & \multicolumn{3}{c}{$E S(5 \%)$} \\
\hline Code & Exposure & Ibovespa* & DnP & Exposure & Ibovespa* & DnP \\
\hline BOVA11 & -2.447523 & -2.427072 & -0.49744 & -3.5049 & -3.41856 & -0.96264 \\
XBOV11 & -2.412602 & -2.301529 & -1.5561 & -3.50897 & -2.9091 & -2.15587 \\
ECOO11 & -2.284445 & -2.192187 & -1.65743 & -2.92827 & -2.8474 & -2.22175 \\
CSMO11 & -1.728038 & -2.167189 & -1.75434 & -2.7191 & -3.06367 & -2.52665 \\
MOBI11 & -3.122594 & -2.167189 & -2.16616 & -4.43126 & -3.06367 & -3.21863 \\
MILA11 & -1.986073 & -2.427072 & -2.46018 & -3.33218 & -3.41856 & -3.72125 \\
SMAL11 & -1.981175 & -2.427072 & -1.88219 & -3.21386 & -3.41856 & -3.25094 \\
UTIP11 & -2.195408 & -2.284352 & -2.47588 & -4.02544 & -2.91086 & -4.22334 \\
DIVO11 & -1.652913 & -2.285992 & -1.20207 & -2.30309 & -2.8645 & -1.95745 \\
FIND11 & -2.154973 & -2.285992 & -1.87622 & -2.93065 & -2.8645 & -2.52625 \\
GOVE11 & -1.796391 & -2.285992 & -1.03904 & -2.43072 & -2.83105 & -1.79080 \\
MATB11 & -2.784453 & -2.286305 & -2.06255 & -3.83078 & -2.8645 & -3.05411 \\
ISUS11 & -1.760262 & -2.285992 & -1.77075 & -2.71213 & -2.83105 & -2.97036 \\
PIBB11 & -3.034901 & -2.948087 & -1.27708 & -4.55112 & -4.2388 & -1.82982 \\
\hline
\end{tabular}

Source: Organized by the Authors

* Results checked for the Ibovespa, with its last observation on 08/29/2013.

For the ES, the greatest exposure was observed for the PIBB11 fund (-4.6\%), possibly influenced by the longest period of existence, with less exposure being observed for the DIVO11 fund (-2.3\%). When analyzed against the Ibovespa benchmark, the PIBB11 continues to present the largest loss of value $(-4.2 \%)$, and the smallest was presented by the ISUS11 fund (-2.8\%). On the other hand, for the ES of the DnP, the largest loss of value was found in the UTIP11 fund (-4.2) and the lowest average loss was found in the BOVA11 fund $(-1)$. 
It should be pointed out that the estimates of exposure presented in Table 3 may be underestimated for the funds with lower share liquidity, if the investor needs to redeem the shares with the administrator.

\subsubsection{Monte Carlo Simulation Analysis}

The descriptive statistics of the daily returns of each of the funds, as presented in Table 2, were the basis for the realization of Monte Carlo Simulations and the application of the risk measurement VaR and ES techniques to the daily variation simulated for ETFs. These simulations enabled the realization of potential results of ETFs against Ibovespa, i.e., additional results consistent with the performance seen in the ETFs.

The use of the ES risk measurement technique incorporated the effect of all results below that identified by VaR, since the expectation of loss verified through ES not only considers the percentile determined in the VaR, but all results of the sample that were below this percentile. Thus, the risk assessed by the ES technique might consider extreme values in the definition of exposure to losses of an investment, as long as the conditional expression for evaluation of the expectation of losses incorporates such extreme results.

Table 4 presents a summary of the results calculated in Monte Carlo simulation for the risk assessment techniques studied.

Table 4 - Comparison of Results Obtained by the Monte Carlo Simulation for the Var and ES Techniques in the Measurement of the Exposure to Risks of Brazilian ETFs

\begin{tabular}{c|c|c|c|c|c|c}
\hline Code & VaR $(5 \%)$ & Ibov VaR (5\%) & DnP VaR (5\%) & ES (5\%) & Ibov ES (5\%) & DnP ES (5\%) \\
\hline BOVA11 & -2.464 & -2.436 & -0.4927 & -3.505 & -3.416 & -0.9655 \\
\hline CSMO11 & -1.711 & -2.206 & -1.772 & -2.729 & -3.068 & -2.529 \\
\hline DIVO11 & -1.682 & -2.252 & -1.206 & -2.306 & -2.863 & -1.96 \\
\hline ECOO11 & -2.277 & -2.227 & -1.657 & -2.922 & -2.851 & -2.225 \\
\hline FIND11 & -2.185 & -2.252 & -1.876 & -2.935 & -2.864 & -2.533 \\
\hline GOVE11 & -1.784 & -2.254 & -1.032 & -2.433 & -2.829 & -1.797 \\
\hline ISUS11 & -1.723 & -2.255 & -1.737 & -2.721 & -2.83 & -2.986 \\
\hline MATB11 & -2.733 & -2.256 & -2.088 & -3.832 & -2.865 & -3.059 \\
\hline MILA11 & -1.954 & -2.439 & -2.443 & -3.334 & -3.419 & -3.725 \\
\hline MOBI11 & -3.133 & -2.203 & -2.17 & -4.433 & -3.06 & -3.221 \\
\hline PIBB11 & -3.022 & -2.939 & -1.273 & -4.552 & -4.239 & -1.83 \\
\hline SMAL11 & -2.023 & -2.44 & -1.889 & -3.216 & -3.421 & -3.247 \\
\hline UTIP11 & -2.214 & -2.26 & -2.477 & -4.043 & -2.912 & -4.251 \\
\hline XBOV11 & -2.423 & -2.266 & -1.5414 & -3.538 & -2.916 & -2.16 \\
\hline SOurce: & & & &
\end{tabular}

Source: Organized by the Authors 
In all cases considered in the study, and as expected based on the definition of the indicators, the use of ES in relation to VaR implied in an increase in the value measured by the evaluation of exposure to losses on investments. The results are generally consistent with the information provided in Table 3, different from the DnP, which resulted in a greater loss against Ibovespa in the Monte Carlo simulations. So, for example, the ES of the DnP presented the largest loss in the PIBB11 and MOBI11 funds, clearly showing that these portfolios have a very different exposure in relation to the Ibovespa index.

The simulations of the VaR $5 \%$ of returns, VaR $5 \%$ of the DnP, ES $5 \%$ of the return, and ES 5\% of the DnP are presented in Table 5.

Table 5 - Additional Statistics Obtained by Monte Carlo Simulation for the Var and ES Techniques in the Measurement of the Exposure to Risks of Brazilian ETFs

\begin{tabular}{|c|c|c|c|c|c|c|}
\hline & Minimum & $\begin{array}{c}\text { First } \\
\text { Quartile }\end{array}$ & Average & Mean & $\begin{array}{c}\text { Third } \\
\text { Quartile }\end{array}$ & Maximum \\
\hline BOVA11 & -2.971 & -2.515 & -2.448 & -2.464 & -2.396 & -2.132 \\
\hline Dnp & -0.656 & -0.5163 & -0.4974 & -0.4927 & -0.4707 & -0.3852 \\
\hline BOVA11 & -4.575 & -3.634 & -3.497 & -3.505 & -3.366 & -2.835 \\
\hline Dnp & -1.4731 & -1.0288 & -0.9607 & -0.9655 & -0.8974 & -0.6365 \\
\hline CSMO11 & -2.103 & -1.749 & -1.721 & -1.711 & -1.675 & -1.394 \\
\hline Dnp & -2.389 & -1.824 & -1.754 & -1.772 & -1.706 & -1.448 \\
\hline CSMO11 & -3.699 & -2.88 & -2.719 & -2.729 & -2.565 & -1.875 \\
\hline Dnp & -3.117 & -2.631 & -2.523 & -2.529 & -2.422 & -1.995 \\
\hline DIVO11 & -2.246 & -1.803 & -1.653 & -1.682 & -1.594 & -1.258 \\
\hline Dnp & -1.9167 & -1.2761 & -1.2021 & -1.206 & -1.039 & -0.8657 \\
\hline DIVO11 & -3.125 & -2.438 & -2.292 & -2.306 & -2.157 & -1.698 \\
\hline Dnp & -3.186 & -2.123 & -1.949 & -1.96 & -1.789 & -1.14 \\
\hline ECOO11 & -3.04 & -2.417 & -2.262 & -2.277 & -2.136 & -1.487 \\
\hline Dnp & -2.389 & -1.714 & -1.657 & -1.657 & -1.559 & -0.882 \\
\hline ECOO11 & -3.689 & -3.064 & -2.922 & -2.922 & -2.786 & -2.176 \\
\hline Dnp & -2.664 & -2.349 & -2.233 & -2.225 & -2.112 & -1.544 \\
\hline FIND11 & -3.229 & -2.32 & -2.155 & -2.185 & -2.125 & -1.554 \\
\hline Dnp & -2.356 & -1.941 & -1.876 & -1.876 & -1.821 & -1.426 \\
\hline FIND11 & -3.82 & -3.085 & -2.927 & -2.935 & -2.771 & -2.188 \\
\hline Dnp & -3.409 & -2.676 & -2.52 & -2.533 & -2.378 & -1.848 \\
\hline GOVE11 & -2.324 & -1.821 & -1.796 & -1.784 & -1.679 & -1.262 \\
\hline Dnp & -1.5542 & -1.0757 & -1.039 & -1.032 & -0.9711 & -0.7832 \\
\hline GOVE11 & -3.247 & -2.555 & -2.428 & -2.433 & -2.305 & -1.806 \\
\hline Dnp & -2.971 & -1.963 & -1.781 & -1.797 & -1.614 & -1.094 \\
\hline ISUS11 & -2.197 & -1.845 & -1.76 & -1.723 & -1.606 & -1.166 \\
\hline Dnp & -2.613 & -1.859 & -1.771 & -1.737 & -1.617 & -1.212 \\
\hline ISUS11 & -6.007 & -3.046 & -2.668 & -2.721 & -2.283 & -1.715 \\
\hline Dnp & -6.416 & -3.35 & -2.916 & -2.986 & -2.517 & -1.813 \\
\hline MATB11 & -3.873 & -2.919 & -2.784 & -2.733 & -2.54 & -1.879 \\
\hline Dnp & -2.716 & -2.25 & -2.058 & -2.088 & -1.962 & -1.518 \\
\hline MATB11 & -5.217 & -4.066 & -3.821 & -3.832 & -3.584 & -2.545 \\
\hline Dnp & -4.691 & -3.289 & -3.032 & -3.059 & -2.796 & -1.974 \\
\hline MILA11 & -2.613 & -2.094 & -1.986 & -1.954 & -1.809 & -1.27 \\
\hline Dnp & -3.023 & -2.529 & -2.46 & -2.443 & -2.388 & -1.915 \\
\hline MILA11 & -4.597 & -3.507 & -3.329 & -3.334 & -3.149 & -2.434 \\
\hline
\end{tabular}


Table 5 - Additional Statistics Obtained by Monte Carlo Simulation for the Var and ES Techniques in the Measurement of the Exposure to Risks of Brazilian ETFs

\begin{tabular}{lrrrrrr}
\hline Dnp & -5.009 & -3.911 & -3.707 & -3.725 & -3.523 & -2.79 \\
\hline MOBI1 & -3.785 & -3.188 & -3.121 & -3.133 & -3.062 & -2.661 \\
Dnp & -2.618 & -2.243 & -2.166 & -2.17 & -2.113 & -1.672 \\
MOBI1 & -5.584 & -4.622 & -4.425 & -4.433 & -4.235 & -3.427 \\
Dnp & -4.256 & -3.374 & -3.211 & -3.221 & -3.054 & -2.331 \\
\hline PIBB11 & -3.555 & -3.084 & -3.034 & -3.022 & -2.97 & -2.545 \\
Dnp & -1.467 & -1.304 & -1.277 & -1.273 & -1.248 & -1.092 \\
PIBB11 & -5.42 & -4.701 & -4.545 & -4.552 & -4.396 & -3.855 \\
Dnp & -2.151 & -1.882 & -1.829 & -1.83 & -1.777 & -1.545 \\
\hline SMAL11 & -2.483 & -2.116 & -1.981 & -2.023 & -1.911 & -1.669 \\
Dnp & -2.41 & -2.028 & -1.882 & -1.889 & -1.778 & -1.388 \\
SMAL11 & -4.142 & -3.365 & -3.208 & -3.216 & -3.057 & -2.536 \\
Dnp & -4.415 & -3.419 & -3.237 & -3.247 & -3.064 & -2.339 \\
UTIP11 & -3.633 & -2.45 & -2.195 & -2.214 & -2.06 & -1.4 \\
Dnp & -3.815 & -2.535 & -2.475 & -2.477 & -2.346 & -1.826 \\
UTIP11 & -11.025 & -4.711 & -3.942 & -4.043 & -3.175 & -2.101 \\
Dnp & -11.597 & -4.946 & -4.143 & -4.251 & -3.328 & -2.439 \\
\hline XBOV11 & -4.087 & -2.513 & -2.413 & -2.423 & -2.262 & -1.677 \\
Dnp & -2.3695 & -1.7273 & -1.5561 & -1.5414 & -1.4218 & -0.7702 \\
XBOV11 & -5.794 & -3.863 & -3.513 & -3.538 & -3.181 & -2.13 \\
Dnp & -3.394 & -2.33 & -2.151 & -2.16 & -1.977 & -1.25 \\
\hline Soun.
\end{tabular}

Source: Organized by the Authors

Note: For each ETF, the first two lines refer to VaR and the others to ES.

\subsection{ANALYSIS AGAINST THE RESPECTIVE INDEXERS OF THE ETFS}

An ETF should provide a performance befitting the results verified for its corresponding stock market benchmark index. Thus, the research assessed the results of ETFs surveyed against each specific benchmark, based on the results obtained from past data and by means of Monte Carlo Simulations.

\subsubsection{Analysis of ETF Historical Data Against the Indexer}

The results verified in the samples of daily performances of ETFs against their respective indexers showed that the funds presented losses greater than those observed in the benchmarks, which can be verified by comparing the exposure of the ETF indicated in the $\mathrm{VaR}$ with that of the index. In addition, the expectation of loss of the funds was greater than that verified by the specific references.

Thus, as can be seen in table 6, the results of ETF funds presented dissonances when compared to their benchmarks, which indicates a risk of divergence between the fund and its benchmark. 
Table 6 - Results of the Market Risk Evaluation Through the Var and ES Techniques for the ETF Funds According to Exposure to Losses in Daily Profitability, Indexer Exposure to Each ETF During the Period and the Performance of the ETF Against Such Benchmark

\begin{tabular}{|c|c|c|c|c|c|c|c|}
\hline \multicolumn{2}{|c|}{ ETF } & \multicolumn{3}{|c|}{$\operatorname{VaR}(5 \%)$} & \multicolumn{3}{|c|}{ ES (5\%) } \\
\hline Code & Indexer & Exposure & Index & DnP & Exposure & Index & DnP \\
\hline BOVA11 & & -2.447523 & -2.427072 & -0.4974438 & -3.504903 & -3.418561 & -0.9626432 \\
\hline CSMO11 & & -1.728038 & -1.539353 & -1.189303 & -2.719101 & -2.268213 & -1.845577 \\
\hline DIVO11 & & -1.652913 & -1.622922 & -0.736854 & -2.303089 & -2.094797 & -1.209865 \\
\hline ECOO11 & & -2.284445 & -1.823213 & -1.416232 & -2.928265 & -2.34236 & -1.984061 \\
\hline FIND11 & & -2.154973 & -2.300714 & -1.607084 & -2.930647 & -2.902278 & -2.253036 \\
\hline GOVE11 & & -1.796391 & -1.665244 & -0.6737318 & -2.430724 & -2.296119 & -1.526401 \\
\hline ISUS11 & & -1.760262 & -1.461324 & -1.303539 & -2.712133 & -2.101801 & -2.446445 \\
\hline MATB11 & & -2.784453 & -2.590113 & -2.260355 & -3.830778 & -3.353939 & -3.20397 \\
\hline MILA11 & & -1.986073 & -2.272047 & -2.298952 & -3.332176 & -3.185075 & -3.627224 \\
\hline MOBI11 & & -3.122594 & -2.852165 & -1.465635 & -4.431256 & -3.843711 & -2.388819 \\
\hline PIBB11 & & -3.034901 & -2.833159 & -1.166706 & -4.551122 & -4.294241 & -1.668801 \\
\hline SMAL11 & & -1.981175 & -1.897291 & -1.559606 & -3.213857 & -2.94402 & -2.689247 \\
\hline UTIP11 & & -2.195408 & -2.011981 & -1.575267 & -4.025437 & -3.417154 & -2.324422 \\
\hline XBOV11 & & -2.412602 & -2.301529 & -1.5561 & -3.508971 & -2.9091 & -2.155866 \\
\hline
\end{tabular}

Source: Organized by the Authors.

\subsubsection{Analysis Through Simulations}

In addition to the analysis of the results based on past performances, 10,000 simulations obtained with Monte Carlo based on parameters of each fund and on the benchmark index were conducted. The results for the simulations are laid out in Table 7.

The simulations confirmed the results verified in the historical data, i.e., the ETF funds presented exposures to losses greater than those recorded for their referential indexes. This divergence in performance was noted by both the $\mathrm{VaR}$ at $5 \%$, and the expectation of loss given by the average of the $5 \%$ worst performances indicated by the ES.

Table 7 - Results of the Monte Carlo Simulations for Market Risk Assessment the by Means of the Var and ES Techniques, for ETF Funds According to the Exposure to Losses in Daily Profitability, Indexer Exposure for Each ETF During the Period and the Performance of the ETF Against Such Benchmark

\begin{tabular}{|c|c|c|c|c|c|c|c|}
\hline \multicolumn{2}{|c|}{ ETF } & \multicolumn{3}{|c|}{$\operatorname{VaR}(5 \%)$} & \multicolumn{3}{|c|}{$E S(5 \%)$} \\
\hline Code & Indexer & Exposure & Index & DnP & Exposure & Index & DnP \\
\hline BOVA11 & & -2.464 & -2.436 & -0.4917 & -3.506 & -3.417 & -0.963 \\
\hline CSMO11 & & -1.712 & -1.544 & -1.1874 & -2.724 & -2.271 & -1.847 \\
\hline DIVO11 & & -1.685 & -1.628 & -0.7136 & -2.308 & -2.101 & -1.2117 \\
\hline ECOO11 & & -2.279 & -1.773 & -1.3836 & -2.921 & -2.412 & -2.072 \\
\hline FIND11 & & -2.189 & -2.194 & -1.628 & -2.927 & -2.855 & -2.251 \\
\hline GOVE11 & & -1.803 & -1.716 & -0.6924 & -2.477 & -2.325 & -1.535 \\
\hline ISUS11 & & -1.723 & -1.505 & -1.2639 & -2.723 & -2.095 & -2.465 \\
\hline MATB11 & & -2.732 & -2.632 & -2.213 & -3.827 & -3.354 & -3.211 \\
\hline MILA11 & & -1.955 & -2.26 & -2.3 & -3.334 & -3.191 & -3.607 \\
\hline MOBI11 & & -3.134 & -2.853 & -1.463 & -4.436 & -3.845 & -2.394 \\
\hline PIBB11 & & -3.022 & -2.839 & -1.159 & -4.549 & -4.291 & -1.67 \\
\hline SMAL11 & & -2.02 & -1.906 & -1.541 & -3.212 & -2.948 & -2.685 \\
\hline UTIP11 & & -2.214 & -1.998 & -1.6 & -4.048 & -3.448 & -2.326 \\
\hline XBOV11 & & -2.419 & -2.264 & -1.5392 & -3.533 & -2.915 & -2.157 \\
\hline
\end{tabular}

Source: Organized by the Authors. 


\section{FINAL CONSIDERATIONS}

For most results, it was observed that ETFs suffered losses in relation to the Ibovespa index, as well as in relation to their respective benchmarks. This difference can be explained by the difficulties faced by the managers to properly replicate the indexers. This aspect can, therefore, suggest the existence of opportunities for arbitrage in the market, given the divergence between the negotiated values of the indexes and the ETFs. With this, this study contributes with the evaluation of the divergence in relation to the indexer in the market of Brazilian ETFs.

Moreover, another aspect seen in this study is that the ES is an indicator that allows for the quantification of greater or lesser exposure to risk than that seen in the VaR, in financial indexes, specifically in ETFs. This difference in risk measured by the techniques results from the incorporation of results below the percentile adopted for calculation of the VaR. This increase in value measured for the exposure to risks of an investment resulting from the adoption of the ES by a financial institution entails the need to adjust of reserves for losses. This implies in a greater financial expenditure to incorporate the trend of losses of an investment with the occurrence of results below the VaR.

However, when using the ES, the financial institution may transfer greater security to market agents regarding its financial applications, which affects the soundness of this organization. Such security comes from the adjustment in the financial provisions that now consider the expectation of loss in investments when overcoming the $\mathrm{VaR}$, thus tending to incorporate the financial impact of negative results in the investments.

For future studies, the specific analysis of the behavior of indexes of the financial sector in different markets is suggested, equally or more developed than the Brazilian market, in order to verify if the conclusions reached in this study are, in fact, either a characteristic or inherent to the market sector in which the institutions operate. Another possibility is the investigation of markets, emergent or not, that have larger amounts of ETFs, as well as the analysis of high frequency data on the Brazilian ETFs, or even the revalidation of the results found herein after a period of greater duration of ETFs in the Brazilian market. In order to complement this and other works about index funds traded in Brazil, a comparative analysis between different ETFs is also suggested, with a uniform timeframe for the sample. 


\section{REFERENCES}

ACERBI, C.; TASCHE, D. Expected shortfall: a natural coherent alternative to value at risk. Economic Notes, v. 31, n. 2, p. 379-388, 2002.

ANBIMA. Associação Nacional das Instituições do Mercado Financeiro. IMA Metodologia. Disponível em: $<$ http://www.andima.com.br/ima/ima_cartilha.asp $>$. Acesso em: 20 abr. 2011.

ARAGÃO, D. D. A Eficiência da precificação e os erros de aderência dos exchange traded funds do mercado brasileiro. 2011. 65 f. Dissertação (Mestrado em Finanças e Economia Empresarial) - Fundação Getúlio Vargas, São Paulo, 2011.

ARTZNER, P. et al. Coherent measures of risk. Mathematical Finance, v. 9, n. 3, 1999.

ARTZNER, P. et al. Thinking coherently. Risk, v. 10, n. 11, 1997.

BACEN. Banco Central do Brasil. Séries temporais. Disponível em: $<$ http://www.bacen.gov.br/?SERIETEMP>. Acesso em: 20 abr. 2011.

BECKERS, S. A survey of risk measurement theory and practice. In: ALEXANDER, C. Risk management and analisys. Chichester: John Wiley \& Sons, 1998. v. 1.

BLACKROCK. iShares ETF valuation terms. 2012. Disponível em:

$<$ http://us.ishares.com/content/stream.jsp?url=/content/en_us/repository/resource/valuation_te rms.pdf\&mimeType=application/pdf $>$. Acesso em: 29 fev. 2012.

BLACKROCK. ETP landscape: industry highlights, year end 2011. 2011. Disponível em: $<$ http://www.blackrockinternational.com/content/groups/internationalsite/documents/literature /etfl_industryhilight_ye11.pdf $>$. Acesso em: 15 fev. 2012.

BM\&FBOVESPA, Bolsa de Mercadorias e Futuros Bovespa. ETF: Exchange Traded Fund. São Paulo, 2008. Disponível em:

$<$ http://www.bmfbovespa.com.br/Pdf/FolhetoETFbaixa.pdf > . Acesso em: 29 fev. 2012.

Índice Bovespa: Ibovespa. 2011. Disponível em

$<\mathrm{http}: / /$ www.bmfbovespa.com.br/indices/

ResumoIndice.aspx? Indice=IBOVESPA\&Idioma=pt-BR $>$ acessado em 20/04/2011. ago. 2013 .

Site institucional. Disponível em: <http://www.bmfbovespa.com.br>. Acesso em: 15

DELLVA, W. L. Exchange-traded funds not for everyone. Journal of Financial Planning, n. 14, p. 110-124, 2001.

DEVILLE, D. Exchange traded funds: history, trading and research. In: ZOPOUNIDIS, C.; DOUMPOS, M.; PARDALOS, P. (Eds.). Handbook of Financial Engineering, p. 67-98, 2008.

DUARTE JUNIOR, A. M. Gestão de riscos para fundos de investimentos. São Paulo: Prentice Hall, 2005. 
FABOZZI, F. J. Mercados, análise e estratégias de bônus: títulos de renda fixa. Rio de Janeiro: Qualitymark, 2004.

FARIAS, M. A. ETFs, PIBB e a Liquidez das Ações. Caderno de Pesquisa Investimento, Fundação Getúlio Vargas, p. 53-57, 2009.

GASTINEAU, G. The benchmark index ETF performance problem. The Journal of Portfolio Management, v. 30, n. 2, p. 96-103, Winter, 2004.

HOOGERHEIDE, L.; VAN DIJK, H. K. Bayesian forecasting of value at risk and expected shortfall using adaptive importance sampling. International Journal of Forecasting, mar. 2010 .

MORGAN, J. P. Risk metrics®: technical document. 4. ed. 1996. Disponível em: $<$ www.jpmorgan.com/RiskManagement/RiskMetrics/RiskMetrics.html>. Acesso em: 13 nov. 2005.

JARES, T. E.; LAVIN, A. M. Japan and Hong Kong exchange-traded funds (ETFs): discounts, returns and trading strategies. Journal of Financial Services Research, v. 25, n. 1, p. 57-69, 2004.

JORION,P. Risk: measuring the risk in value at risk. Financial Analysts Journal; v. 52, n. 6, 1996.

JORION, P. Financial Risk Manager: handbook. 2. ed. Chichester: John Wiley \& Sons, 2003.

MALUF, Y. S. Mercado brasileiro de fundos ETFs: evidências empíricas de arbitragem. 2011. 58 p. Monografia (Administração) - Departamento de Administração, Universidade de Brasília (UnB), Brasília, 2011.

PENA, M. A convergência do VaR para a DnP normalizada. In: CONGRESSO BRASILEIRO DOS FUNDOS DE PENSÃO, 26., 2005, Porto Alegre (RS). Anais... Porto Alegre: Abrapp, 2005.

POTERBA, J.M.; SHOVEN, J.B. Exchange-traded funds: a new investment option for taxable investors. The American Economic Review, v. 92, n. 2, may 2002.

RAMASWAMY, S. BIS Working Papers n. 343. Market structures and systemic risks of exchange-traded funds. Bank for International Settlements, Basel, 2011.

ROCKAFELLAR, R. T.; URYASEV, S.; ZABARANKIN, M. Master funds in portfolio analysis with general deviation measures. The Journal of Banking and Finance, v. 29, 2005.

ROMPOTIS, G. G. The performance of actively managed exchange-traded funds. Journal of Index Investing, v. 1, n. 4, summer 2011.

RIBEIRO FILHO, J.; LA ROCQUE, E.; SILVA, W. Monitoramento de risco: aplicação do conceito de value at risk para fundos de pensão. Resenha BMF n. 122.

$<$ http://www2.bmf.com.br/cimConteudo/W_ArtigosPeriodicos/01544102.pdf $>$. Acesso em: out. 2005. 
SILVA, A. C. R. et al. Análise da coerência de medidas de risco no mercado brasileiro de ações e desenvolvimento de uma metodologia híbrida para o expected shortfall. In: ENCONTRO DA ASSOCIAÇÃO NACIONAL DE PÓS-GRADUAÇÃO EM ADMINISTRAÇÃO (ENANPAD), 29., 2005, Brasília (DF). Anais... Brasília: ANPAD, 2005.

SO, M. K. P.; WONG, C. Estimation of multiple period expected shortfall and median shortfall for risk management, Quantitative Finance, set. 2010. Disponível em: $<$ http://ssrn.com/abstract=1573523>. Acesso em: 03 abr. 2012.

YANG, J.; WANG, T. Nonlinearity, data-snooping and stock index ETF return predictability. European Journal of Operational Research, v. 200, p. 498-507, 2011.

ZHU, D.; GALBRAITH, J. W. Modeling and forecasting expected shortfall with the generalized asymmetric Student-t and asymmetric exponential power distributions, Journal of Empirical Finance, v. 18, n. 4, set. 2011. 